\title{
ПРОБЛЕМЫ ФИНАНСОВОГО ПРАВА
}

\section{Я.Н. Игнатов* \\ ПРАВОВОЕ РЕГУЛИРОВАНИЕ ФОНДОВОГО РЫНКА В УСЛОВИЯХ ФИНАНСОВОГО КРИЗИСА}

Ключевые слова: финансовый кризис, деривативы, сделки на разницу, биржи, хэдж-фонды, фондовый рынок, Международный Валютный Фонд (МВФ).

\section{Y.N. Ignatov. Legal Regulation of the Stock Market in a Financial Crisis}

This paper seeks to draw lessons for financial sector regulation (EU, USA \& Russia) and supervision and central bank liquidity management from the ongoing crisis, focusing principally on implications for the future rather than on immediate crisis management policies.

Inadequacies in macroeconomic policies and the design of the international financial architecture exposed in the crisis will also have to be addressed to make the suggested changes in the regulatory framework effective.

Основным принципом правового регулирования отношений на финансовом рынке является принциип свободного движения капитала или финансовых средств. Он закрепляется как в конституционном праве Российской Федерации (ч. 1 ст. 8 Конституции РФ 1993 г.), так и в конституционных нормах некоторых федеративных государств (ч. 4 ст. 1 Конституции Боснии и Герцеговины 1995 г.) $)^{1}$, а также международном и европейском праве (ст. 56-60 Договора о Европейском союзе (Маастрихского договора) 1992 г. $^{2}$ в редакции Амстердамского договора 1997 г., Договор о Таможенном союзе и Едином экономическом пространстве от 26 февраля $1999 \Gamma^{3}$, Договор об учреждении Евразийского экономического сообщества 2000 г., Соглашение о формировании Единого экономического пространства 2003 г. $)^{5}$.

Но если в рамках конституционно-правового регулирования данный принцип служит обеспечению единства экономического пространства государства и развитию экономики, обеспечивая тем самым государственный суверенитет, то широкое его использование в международно-правовом регулировании не столь однозначно.

\footnotetext{
* Аспирант Московской государственной юридической академии имени О.Е. Кутафина. [online@kit-trust.com]

1 Часть 4 ст. 1 Конституции Боснии и Герцеговины 1995 г.

2 Статьи 56-60 Договора о Европейском союзе (Маастрихского договора) 1992 г. в редакции Амстердамского договора 1997 г.

3 Договор о Таможенном союзе и Едином экономическом пространстве от 26 февраля 1999 г. // СПС «КонсультантПлюс».

4 Договор об учреждении Евразийского экономического сообщества 2000 г. // СПС «КонсультантПлюс».

5 Соглашение о формировании Единого экономического пространства 2003 г. // СПС «КонсультантПлюс».
} 
В настоящее время, например, доля глобальных инвесторов на российском фондовом рынке составляет около 50 \%, с конца 2006 г. большая часть сделок с российскими акциями стала осуществляться на зарубежных фондовых биржах.

По мнению известного венгерского правоведа и судьи Европейского суда по правам человека А. Шайо, «современным демократиям приходится обслуживать гораздо более масштабное и более важное в социальном отношении государство; они должны решать общественные проблемы, требующие более динамичной, быстрой реакции, чем во времена Токвиля. В эпоху электронной котировки биржа может развалиться за десять минут, увлекая за собой национальную и мировую экономику. Поэтому механизм конституционных решений для большей эффективности должен удовлетворять и новым требованиям» ${ }^{6}$.

Примером такой ситуации является кризис на финансовом рынке, начавшийся в США в 2007 г. на рынке ипотеки и перекинувшийся на другие страны, который Дж. Сорос назвал сильнейшим за последние 60 лет $^{7}$. Последствия данного кризиса мы видим и в 2011 г. в России. Сложный характер влияния процессов глобализации на государственный суверенитет, фондовые рынки и рынки капиталов в последнее время все больше отмечается учеными-конституционалистами. Например, по мнению председателя Конституционного Суда Российской Федерации В.Д. Зорькина, «именно сейчас от международного сообщества специалистов по конституционному праву особенно требуется точный анализ современного понятия полноценного суверенитета» ${ }^{8}$.

По мнению С.Н. Сильвестрова, заместителя директора ИЭ РАН «глобализация диктует модернизацию моделей социальной организации, к которым относятся прежде всего национальные государства. Национальные власти шаг за шагом теряют возможность эффективно использовать такие традиционные рычаги макроэкономического регулирования, как импортные барьеры и экспортные субсидии, курс национальной валюты или ставка рефинансирования центрального банка... Возникает несоответствие полномочий у традиционных государственных институтов принятия решений и международных институтов или надгосударственных органов, в руки которых быстро переходит контроль над основными ресурсами и экономическими процессами. Нарастает объем полномочий, делегируемых от государства наднациональным органам и универсальным глобальным организациям. Первыми сворачиваются функции проведения самостоятельной денежно-кредитной, экспортно-импортной и валютной политики» 9 .

6 Шайо A. Самоограничение власти (краткий курс конституционализма) / пер. с венгр. М., 2001. С. 20-28.

7 См.: Сорос Дж. Финансовый рынок: Сильнейший кризис за 60 лет // Ведомости. 2008. 24 янв.

8 Зорькин В.Д. Об угрозах конституционному строю в XXI в. и необходимости проведения правовой реформы в России // Журнал российского права. 2004. № 6; Зорькин В.Д. Судебная защита между глобализацией и суверенитетом // Росс. газ. 2007. 18 июля. С. $23-54$.

9 Сильвестров С.Н. Индикативное планирование в стратегии развития // Научный эксперт. 2008. № 1 . 
Все активнее развивается процесс унификации публично-правовых механизмов государственного и правового регулирования отношений на национальных финансовых рынках. Большую роль здесь играет деятельность международных экономических организаций. В сфере банковского надзора - это «Основополагающие принципы эффективного банковского надзора» 2006 г. ${ }^{10}$, разработанные Базельским комитетом по банковскому надзору. В сфере регулирования рынка ценных бумаг - это «Цели и принципы регулирования в области ценных бумаг» 1998 г., разработанные Международной организацией комиссий по ценным бумагам ${ }^{11}$. В сфере страхования - «принципы» и «руководства» Международной ассоциации страхового надзора.

В ряде работ известных правоведов содержатся предложения о широком использовании зарубежного и международного регулирования отношений на финансовом рынке. Значительно меньшее число работ затрагивает вопросы обеспечения национальных интересов, национальной безопасности и государственного суверенитета при формировании и реализации политики правового регулирования отношений на финансовых рынках.

Таким образом, в современной юридической науке при исследовании процессов глобализации в сфере финансовых рынков недостаточно уделяется внимания ее негативным факторам, в том числе угрозам государственному суверенитету. Как уже отмечено, в правовой науке комплексного анализа указанных вопросов до настоящего времени не проводилось.

Масштабы антикризисных мер, принимаемых в российской экономике для преодоления финансового кризиса, в сочетании с целенаправленной и системной политикой по созданию необходимых структурных основ на самом рынке, частично вывели российский фондовый рынок из кризиса с наименьшими потерями, но кризисные явления были заметны в экономике и на фондовом рынке как весь 2010 г., так и в 2011 г.

В 2012 г. Россия также входит с определенной финансовой нестабильностью, так как фондовый рынок страны зависит от мировых фондовых индексов, постоянно снижающихся по причине фактического дефолта Греции, снижения суверенных рейтингов Италии и Испании.

Анализируя тему правового регулирования фондового рынка, следует проанализировать деятельность специализированной службы по финансовым рынкам. Уполномоченным государственным органом, реализующим функции государственного регулирования профессиональной деятельности на рынке ценных бумаг, является ФСФР России ${ }^{12}$.

10 Основополагающие принципы эффективного банковского надзора 2006 г., разработанные Базельским комитетом по банковскому надзору.

11 Цели и принципы регулирования в области ценных бумаг 1998 г., разработанные Международной организацией комиссий по ценным бумагам.

12 Постановление Правительства РФ от 30 июня 2004 г. № 317 // СПС «КонсультантПлюс». 
ФСФР образована в соответствии со ст. 112 Конституции Российской Федерации и Федеральным конституционным законом от 13 декабря 1997 г. № 2-ФКЗ «О Правительстве Российской Федерации» ${ }^{13}$ на основании Указа Президента Российской Федерации от 9 марта 2004 г. № 314 «О системе и структуре федеральных органов исполнительной власти» (далее - Указ № 314) ${ }^{14}$.

Постановлением Правительства РФ от 30 июня 2004 г. № 317 «Об утверждении Положения о Федеральной службе по финансовым рынкам» утверждено Положение о ФСФР России (далее - Положение) $)^{15}$. В соответствии с Положением ФСФР России - федеральный орган исполнительный власти, осуществляющий функции по принятию нормативных правовых актов, контролю и надзору в сфере финансовых рынков (за исключением страховой, банковской и аудиторской деятельности).

Проанализировав указанное Постановление Правительства, необходимо отметить, что в нарушение Указа № 314 при разработке и утверждении Положения, на основании которого юридическое лицо (ФСФР России) осуществляет свою деятельность, в нем не были учтены полномочия и функции, обязательные к исполнению ФСФР России, исходя из требований Федерального закона от 22 апреля 1996 г. № 39-Ф3 «О рынке ценных бумаг» ${ }^{16}$, а также функции упраздненной Федеральной комиссии по рынку ценных бумаг (ФКЦБ) $)^{17}$, такие как координация деятельности федеральных органов исполнительной власти по вопросам регулирования рынка ценных бумаг, ведение реестра саморегулирующих организаций профессиональных участников рынка ценных бумаг, ведение реестра выданных, приостановленных и аннулированных лицензий.

Данная правовая коллизия подтверждена в Отчете о результатах контрольного мероприятия «Проверка эффективности в 2008 г. действующего законодательства и нормативной правовой базы о финансовом рынке и рынке ценных бумаг в целях стабилизации финансовой системы в ФСФР, в Минфине РФ», утвержденного на коллегии Счетной палаты Российской Федерации 15 мая 2009 г. решением № 24К (661) ${ }^{18}$.

Кроме того, анализируя Отчет Счетной палаты следует отметить, что Счетная палата выявила другие нарушения в работе ФСФР России, а именно - на-

13 СПС «КонсультантПлюс».

14 Там же.

15 Там же.

16 Там же.

17 Указ Президента РФ от 9 марта 2004 г. № 314 «О системе и структуре федеральных органов исполнительной власти» // СПС «КонсультантПлюс».

18 Отчет Счетной палаты Российской Федерации от 15 мая 2009 г. № 24К (661) «О результатах контрольного мероприятия «Проверка эффективности в 2008 г. действующего законодательства и нормативной правовой базы о финансовом рынке и рынке ценных бумаг в целях стабилизации финансовой системы в Федеральной службе по финансовым рынкам и Министерстве финансов Российской Федерации». 
рушение требований Типового регламента внутренней организации федеральных органов исполнительной власти и Типового регламента взаимодействия федеральных органов исполнительной власти, утвержденных, соответственно, постановлениями Правительства РФ от 28 июля 2005 г. № $452^{19}$ и от 19 января 2005 г. № $30^{20}$. Отмечено, что не разработаны административные регламенты по осуществлению ряда возложенных на ФСФР государственных функций. Так, административный регламент по принятию нормативных правовых актов в сфере финансовых рынков не разработан и не утвержден, некоторые административные регламенты приняты с нарушением установленных Правительством РФ сроков.

Необходимо отметить, что непринятие административных регламентов привело к отсутствию установленных сроков, неопределенности административных процедур и действий ФСФР, а также к отсутствию порядка взаимодействия между ее структурными подразделениями и должностными лицами.

Особенно стоит отметить слабость как правового регулирования, так и в целом государственного, так как ФСФР России, ссылаясь на отсутствие соответствующих поручений со стороны Правительства Российской Федерации, за период кризиса ни разу не направляла в Правительство доклады по развитию в 2008 г. кризисной ситуации на фондовом рынке и по вопросам стабилизации финансовой системы.

Согласно Отчету: «Принимаемые меры по недопущению углубления кризисной ситуации в 2008 г. на фондовом рынке в виде приостановки торгов, которые чаще всего происходили в сентябре и октябре, привели к фактическому перетоку ликвидности с российского фондового рынка на Лондонскую фондовую биржу» ${ }^{21}$.

Выпуск и обращение государственных ценных бумаг относятся к компетенции Министерства финансов. Федеральный закон «О рынке ценных бумаг» вообще не регулирует вопросы, связанные с федеральными государственными ценными бумагами, с ценными бумагами субъектов Федерации и муниципальными государственными бумагами. Законодательное регулирование этого блока фондового рынка и контроль за ним возложены на Министерство финансов²2.

По Закону «О рынке ценных бумаг» Центральный банк $Р \Phi^{23}$ является подчиненным органом в вопросах регулирования эмиссии ценных бумаг кредитных организаций. ФСФР передает ему функции законодательного обеспечения эмиссии и обращения ценных бумаг кредитных организаций и их регистрации, конт-

19 СПС «КонсультантПлюс».

20 Там же.

21 Отчет Счетной палаты РФ. С. 89.

22 Федеральный закон от 2 декабря 2009 г. № 308-Ф3 «О федеральном бюджете на 2010 год и на плановый период 2011 и 2012 годов» // СПС «КонсультантПлюс».

23 Федеральный закон от 10 июля 2002 г. № 86-Ф3 «О Центральном банке Российской Федерации (Банке России)» // СПС «КонсультантПлюс». 
роля за соблюдением эмитентами законодательства. Вопросы лицензирования деятельности банков на рынке ценных бумаг по закону и по нормативным актам находятся в компетенции ФСФР. В то же время именно Центральный банк является главным агентом Министерства финансов на рынке государственных ценных бумаг и именно он отвечает за финансовое регулирование фондового рынка. Именно Центральному банку принадлежат те инструменты, с помощью которых он может регулировать ликвидность финансовой системы, валютный курс, политику процентных ставок и состояние финансового рынка. Центральный банк является и агентом валютного контроля, отвечая за вход и выход капитала на российскую территорию. Существенную роль должен играть Центральный банк и при реализации функции антикризисного управления фондовым рынком.

На основании анализа указанных документов предлагается необходимым для преодоления кризиса на рынке ценных бумаг продолжить антикризисные меры со стороны основных регулирующих органов, в частности, разработать следующие меры по усилению регулирования рынка ценных бумаг со стороны ФСФР, Минфина, Банка России.

Предлагаемые меры по регулированию рынка Банком России:

- создание банковского консорциума во главе с ЦБ РФ. В состав консорциума должны входить крупные банки: Банк России, Сбербанк РФ, Внешторгбанк, Внешэкономбанк, Газпромбанк, Россельхозбанк, Банк Москвы и др. Задачи консорциума: массовая скупка ценных бумаг для увеличения спроса на них; поддержание процентных ставок на фондовом и кредитном рынках; стабилизация доходности государственных ценных бумаг и курсов корпоративных бумаг;

- создание ЦБ РФ совместно с ФСФР единой депозитарной сети по государственным и корпоративным ценным бумагам. Это позволит иметь полную информацию о капиталопотоках на фондовом рынке, обеспечить практически абсолютную сохранность ценных бумаг, пресекать недоброкачественные сделки на рынке;

- административные меры в отношении участников рынка, проводимые ЦБ РФ совместно с ФСФР: приостановление права коммерческих банков использовать короткую позицию по денежным средствам; недопущение их к операциям РЕПО; отстранение банков от торгов в случае их игры на понижение котировок ОФЗ и корпоративных облигаций.

Предлагаемые меры по регулированию рынка Министерством финансов РФ:

- изменение структуры рынка госбумаг за счет увеличения выпуска наиболее надежных ценных бумаг - облигаций сберегательных займов;

- разработка рейтинга государственных и корпоративных ценных бумаг. Присваивать рейтинги облигациям различных эмитентов должно рейтинговое агентство, созданное при непосредственном участии Минфина.

Регулирование биржевых операций ФСФР:

- наделение ФСФР функциями антикризисного регулятора рынка. Необходимо ввести на биржи представителей ФСФР и наделить их функциями оперативных регуляторов; 
- варьирование суммарной короткой позицией участников рынка. В предкризисный период короткая позиция по деньгам могла составлять 200-300 \% собственных средств участников торгов. Однако курсы акций в течение короткого времени могут резко измениться. Практика показала, что они могут снизиться за четыре дня на 40-60\%. Если инвесторы вложили в акции весь собственный капитал и заемные средства в размере свыше $100 \%$ собственного капитала, их массовое банкротство неминуемо. Поэтому короткую позицию по деньгам целесообразно установить в размере 50-70 \% от общей суммы собственных средств участников торгов;

- важную роль в контроле над игроками на понижение курсов акций играет пороговое значение короткой позиции по бумагам. Рост коротких позиций по бумагам - это предвестник начала крупномасштабной игры на понижение и, как следствие, усиления кризиса. Короткую позицию по бумагам необходимо ограничить 40-50 \% общей рыночной стоимости бумаг на счетах депо;

- ограничение сделок РЕПО. Кредиты брокеров в ряде случаев превышали собственные средства их клиентов в 2-3 раза ${ }^{24}$. Сделки РЕПО осуществлялись по определенной схеме. Участник рынка производил короткую продажу (в рамках РЕПО) акций, купленных на маржинальные кредиты и собственные средства. На полученные деньги приобретались новые акции, которые также продавались в рамках операции РЕПО. Затем вновь на полученные деньги приобретались акции и т.д. Возникает пирамида. Подобные сделки очень эффективны на растущем рынке. Но в условиях падения курсов акций кредиторы начинают принудительно погашать маржинальные кредиты, если они превышают собственные средства заемщика. Чтобы расплатиться с кредиторами, заемщики продают «репованные» акции по любой цене. В результате курсы акций еще сильнее падают и т.д. Именно по такой схеме развивался кризис в августесентябре 2008 г. Поэтому операции РЕПО, совершаемые на маржинальные кредиты, должны быть ограничены 10 \% общей суммы сделок на конкретной бирже, а совершаемые на собственные средства - $20 \%$ от общей суммы сделок на конкретной бирже.

Важная роль в контроле за соблюдением исполнения участниками фондового рынка законодательства, в том числе федеральных законов «О рынке ценных бумаг», «Об инвестиционных фондах», отводится судебным инстанциям, которые активно применяют законодательство в сфере финансового рынка и рассматривают иски участников фондового рынка, в том числе оспаривающие нормативно-правовые акты ФСФР России.

В качестве примера можно привести дело из картотеки Арбитражного суда г. Москвы № А-40-170046/09-119-1247 о признании недействительным приказа ФСФР России от 1 декабря 2009 г. № 09-3849/пз-и²5. Данным приказом ФСФР

24 Доклад «О проблемах и перспективах развития российского фондового рынка в условиях кризиса мировой финансовой системы». Институт развития фондового рынка.

25 Официальный сайт Арбитражного суда г. Москвы. 
России аннулировала лицензию на осуществление деятельности негосударственного пенсионного фонда по пенсионному обеспечению и пенсионному страхованию НПФ «Отчизна», а последняя - оспорила данный приказ в Арбитражном суде г. Москвы, считая его недействительным. Проанализировав доводы сторон, суд пришел к выводу, что в удовлетворении иска НПФ «Отчизна» к ФСФР России должно быть отказано в связи с тем, что фонд неоднократно нарушал законодательство, в частности, Федеральный закон от 7 мая 1998 г. № 75-Ф3 «О негосударственных пенсионных фондах» 2 .

Своим решением Арбитражный суд прекратил деятельность фонда, не исполняющего закон, указав при этом, что реализация и выполнение субъектами отношений, предусмотренных данным Законом и актами ФСФР России, регулирующими вопросы о негосударственном пенсионном обеспечении, о трудовых пенсиях, позволяет достигнуть единства внутренней политики государства в сфере аккумулирования пенсионных взносов, размещение и организацию их размещения, назначение и начисление негосударственных пенсий участникам фонда.

Кроме того, следует отметить значительную роль в совершенствовании законодательства Высшего Арбитражного Суда Российской Федерации (далее ВАС РФ). Президиум ВАС РФ дал возможность Федеральной службе по финансовым рынкам защищать миноритарных акционеров компаний через суд, а не только путем вынесения предписаний. 1 апреля 2010 г. Президиум ВАС решил в пользу ФСФР дело 27 в котором служба требовала от мажоритарного акционера компании соблюдать закон при выкупе акций у миноритарных акционеров. ООО «Прайс-инвест» в Челябинской области 10 декабря 2007 г. купило 90,87 \% акций ОАО «Торгово-производственная компания "Урал"», а затем 16 января 2008 г. направило в компанию обязательную оферту, предусматривающую выкуп акций у миноритариев в срок до 7 апреля 2008 г. В региональное отделение ФСФР документы по обязательной оферте «Прайс-инвест» представил не в течение 15 дней, как требует Закон «Об акционерных обществах», а только 19 августа 2008 г. - после получения предписания службы от 30 июня 2008 г. ФСФР нашла в условиях оферты ряд нарушений Закона «Об акционерных обществах» ${ }^{28}$, касавшихся определения цены выкупаемых акций и банковской гарантии. ФСФР подала к «Прайс-инвесту» иск о приведении обязательной оферты в соответствие с требованиями закона. Арбитражный суд Челябинской области 10 февраля 2009 г. иск удовлетворил, но апелляционная и кассационная инстанции встали на сторону мажоритарного акционера. Эти суды решили, что достаточной мерой со стороны

26 Федеральный закон от 7 мая 1998 г. № 75-Ф3 «О негосударственных пенсионных фондах» // СПС «Гарант».

27 Официальный сайт Высшего Арбитражного Суда РФ. Дело по иску ФСФР к ООО «Прайс-инвест» о приведении обязательной оферты в соответствие с требованиями Закона «Об акционерных обществах».

28 Федеральный закон от 26 декабря 1995 г. № 208-Ф3 «Об акционерных обществах» // СПС «Гарант». 
ФСФР было направление «Прайс-инвесту» предписания, и по закону миноритарные акционеры могут только требовать от мажоритария возмещения убытков. Президиум ВАС 1 апреля 2010 г. оставил в силе решение суда первой инстанции, поддержавшего ФСФР. По мнению судей ВАС, Закон «Об акционерных обществах» дает ФСФР право подавать иски в защиту миноритариев, тем более что вынести «Прайс-инвесту» предписание об устранении нарушений в условиях оферты ФСФР уже не могла - срок оферты истек.

Усиление роли ФСФР в вопросе защиты интересов миноритариев является необходимой мерой правового регулирования для российского фондового рынка, так как права миноритарных акционеров в России нарушаются регулярно. Несмотря на такую организационно-правовую форму, как ОАО, большинство компаний по сути являются частными с одним контролирующим акционером, который не считается с миноритариями. В мировой практике компании публичны, в них работает процедура собраний акционеров и советов директоров. В России ключевые решения в результате принимает, как правило, контролирующий акционер. Основными нарушениями прав миноритариев можно назвать «размывание долей и перевод активов на другие компании». Комментируя решение Президиума ВАС, глава ФСФР в 2007-2011 гг., а ныне - заведующий кафедрой международных финансов МГИМО В.Д. Миловидов заявил, что «такое право должно применяться в конкретных случаях с учетом конкретных обстоятельств ${ }^{29}$.

Следует отметить несколько основных причин возникновения кризиса на рынке ценных бумаг России.

Во-первых, чрезмерно быстрый рост капитализации рынка. В середине 2001 г. она составляла около 50 млрд долл., в январе 2006 г. - более 620 млрд, в мае 2008 г. - 1,6 трлн долл. В России в начале века капитализация рынка акций в процентах к ВВП была в 9-10 раз ниже среднемирового уровня. В 20082009 гг. она превысила этот уровень ${ }^{30}$.

Во-вторых, рост более чем в 20 раз (в пересчете на доллары) эмиссии корпоративных облигаций в 2001-2007 гг. Хотя объем этого рынка сравнительно невелик, чрезвычайно высокие темпы роста перегрели его ${ }^{31}$.

В-третьих, переоценка стоимости акций. В ряде случаев инвесторы приобретали ценные бумаги по явно завышенной цене. Так, акции СеверсталиАвто $^{32}$ по показателю отношения полной стоимости компании к выручке были размещены на 15-20 \% дороже, чем бумаги таких автогигантов, как «Хонда», «Ниссан», «Тойота» и др. По показателю «отношение капитализации к чистой прибыли» $(\mathrm{P} / \mathrm{E})$ акции российской шинной компании «Амтел» ${ }^{33}$ были разме-

29 Коммерсантъ. 2010. 2 апр. С. 9.

30 Информация с официального сайта ММВБ.

31 Информация с официального сайта ФСФР России.

32 http://www.sollers-auto.com/ru/. Официальный сайт компании.

33 http://www.amteltyre.com/. Официальный сайт компании. 
щены на уровне 32 , в то время как акции лидеров мировой шинной индустрии компаний Michelin и Bridgestone, соответственно, 13 и 17. Переоценка стоимости ценных бумаг привела к особенно быстрому снижению курсов этих акций в период кризиса.

Начавшийся в 2007 г. финансовый кризис на ипотечном рынке привел к обесценению стоимости практически всех залоговых инструментов. В результате долговая пирамида стала рушиться, способствуя развитию мирового кризиса на перегретом рынке акций. Преобладание на российском рынке акций нерезидентов еще более усилило его дестабилизацию. Только осенью 2008 г. иностранные инвесторы вывели с российского фондового рынка свыше 30 млрд долл. ${ }^{34}$. В результате действия этих факторов на российском рынке ценных бумаг возник кризис. Индекс РТС в мае 2008 г. приближался к отметке 2500, а в январе 2009 г. упал ниже 500 пунктов. Курсы акций ведущих компаний снизились в 2-5 раз. Капитализация рынка акций сократилась более чем на 1,2 трлн долл. ${ }^{35}$.

Серьезно пострадал от кризиса и рынок корпоративных облигаций. С мая 2008 г. по май 2009 г. произошло 172 дефолта, включая погашение облигаций, выплату по купонам и офертам (предусмотренных в проспекте эмиссии облигаций досрочных погашений) ${ }^{36}$. При этом совокупный объем выплат по облигациям (погашению, купонам и офертам) постоянно растет. В сентябре 2008 г. он составил 76 млрд руб., в декабре - 117 млрд, в июне 2009 г. - почти 150 млрд ${ }^{37}$.

Кризис на фондовом рынке негативно повлиял на развитие реального сектора. Из-за падения курсов акций российских корпораций возникла острая ситуация с величиной залога, под который корпорации брали кредиты. Дело в том, что если в течение действия кредитного договора стоимость ценных бумаг упала, то кредитор может потребовать досрочного возврата части кредита или увеличения числа ценных бумаг, сданных в залог. Некоторые российские предприятия оказались на грани банкротства.

Кризис привел к сокращению доходов реального сектора от эмиссии акций. В России она стремительно росла с 2004 г., тогда акционерные общества страны разместили на открытом рынке акций на сумму 638 млн, а в 2007 г. - уже более чем на 22 млрд долл. В 2008 г. объем размещения акций на открытом рынке снизился по сравнению с 2007 г. более чем в 10 раз (при этом практически все акции были размещены в первом полугодии, т.е. еще до обострения кризиса) ${ }^{38}$.

Кризис оказал негативное влияние и на бюджетную систему. Доходность ОФЗ возросла с 5,25 \% в мае 2008 г. до 14,09 - в феврале 2009 г. Заимствования на внутреннем рынке стали для государства в 2,7 раза дороже. В последние годы за счет доходов от выпуска госбумаг финансируются расходы федераль-

34 Информация с официального сайта ЦБ РФ.

35 Информация с официального сайта ФСФР России.

36 Там же.

37 Там же.

38 Там же. 
ного бюджета на погашение внешнего госдолга. Большую его часть составляют еврооблигации, в которые конвертирован долг России Лондонскому клубу кредиторов. В целом доходы корпоративного сектора и бюджетной системы от выпуска ценных бумаг со второй половины 2008 года стали снижаться. В январе-июле 2009 г. они приняли отрицательное значение ${ }^{39}$. Произошло это как за счет резкого уменьшения выпуска акций и облигаций, так и за счет существенного роста расходов на обслуживание долговых бумаг.

Важным последствием кризиса для банковской системы стали убытки от снижения курсов акций и облигаций. За июль-октябрь такие убытки составили почти 100 млрд руб. ${ }^{40}$. В этих условиях Банк России был вынужден изменить учет стоимости ценных бумаг. Акции и облигации, купленные в первой половине 2008 г., было разрешено оценивать по стоимости на 1 июля 2008 г., т.е. по докризисным ценам. Переоценка позволила банкам получить в ноябре-декабре 2008 г. около 60 млрд руб. ${ }^{41}$.

К основным направлениям совершенствования законодательства Российской Федерации в этой сфере следует отнести:

- расширение перечня видов активов, которые могут быть использованы для целей секьюритизации;

- расширение круга прав требования, которые могут использоваться для целей секьюритизации;

- введение законодательных ограничений на возможность признания уступки прав требования недействительной;

- определение требований к эмитентам ценных бумаг, выпускаемых при секьюритизации;

- создание механизмов повышения кредитного качества ценных бумаг;

- уточнение законодательства Российской Федерации о ценных бумагах в части специфики ценных бумаг, обеспеченных активами.

В настоящее время развитие рынка ипотечных ценных бумаг сдерживается в связи с тем, что окончательно не сформирована нормативная правовая база в этой сфере.

В соответствии с п. 1.3.2 «Концепции развития гражданского законодательства Российской Федерации» (одобрена решением Совета при Президенте РФ по кодификации и совершенствованию гражданского законодательства от 7 октября 2009 г. $)^{42}$ основными проблемами развития секьюритизации являются: фрагментарное регулирование залога прав (требований), строго формальные процедуры уступки прав (требований), невозможность уступки прав (требований), которые

39 Информация с официального сайта ЦБ РФ.

40 Там же.

41 Информация с официального сайта ЦБ РФ.

42 «Концепция развития гражданского законодательства Российской Федерации» (одобрена решением Совета при Президенте РФ по кодификации и совершенствованию гражданского законодательства от 7 октября 2009 г.) // СПС «КонсультантПлюс». 
не могут быть индивидуализированы на момент их уступки, невозможность уступки прав (требований) в отношении еще не существующего права, которое не оспаривается и не обусловлено встречными предложениями (сейчас возможна уступка будущих прав (требований) только в рамках факторинга). Большинство этих проблем может быть решено в рамках совершенствования общих положений о замене стороны в обязательстве - об уступке прав по будущим обязательствам, об оптовой уступке, об ответственности цедента за действительность уступленного требования и т.д., а также совершенствования положений гл. 43 ГК РФ.

Для формирования полноценного рынка ипотечных ценных бумаг необходима реализация следующих первоочередных мер:

- завершение разработки нормативной правовой базы рынка ипотечных ценных бумаг;

- обеспечение возможности инвестирования в ипотечные ценные бумаги средств крупных институциональных инвесторов;

- $\quad$ реализация мер государственной поддержки рынка ипотечных ценных бумаг;

- разработка и внедрение механизмов повышения кредитного качества ипотечных ценных бумаг (залог банковских счетов, введение счетов «эскроу»);

- увеличение инвестиционного спроса на ипотечные ценные бумаги за счет стандартизации ипотечных кредитов и эффективного формирования пулов;

- развитие инфраструктуры рынка ипотечных ценных бумаг, включая формирование новых институтов (ипотечные агенты, сервисные агенты, доверительные управляющие).

Можно выделить ключевые проблемы развития российского фондового рынка, которые требуют первоочередного решения:

1. Целевая переориентация рынка ценных бумаг с первоочередного обслуживания финансовых запросов государства и перераспределения крупных пакетов акций на выполнение своей главной функции - направление свободных денежных ресурсов на цели восстановления и развития производства в России.

2. Преодоление негативно влияющих внешних факторов, т.е. хозяйственного кризиса, политической и социальной нестабильности.

3. Улучшение законодательства и контроль за выполнением этого законодательства.

4. Повышение роли государства на фондовом рынке, для чего необходимо следующее:

- создание государственной долгосрочной концепции и политики действий в области восстановления рынка ценных бумаг и его текущего регулирования (окончательный выбор модели фондового рынка), а также определение доли источников финансирования хозяйства и бюджета за счет выпуска ценных бумаг;

- необходимость преодоления раздробленности и пересечения функций многих государственных органов, регулирующих рынок ценных бумаг;

- ускоренное, опережающее создание жесткой регулятивной инфраструктуры рынка и ее правовой базы; 
- создание системы отчетности и публикации макро- и микроэкономической информации о состоянии рынка ценных бумаг;

- гармонизация российских и международных стандартов, используемых на рынке ценных бумаг;

- создание активно действующей системы надзора за небанковскими инвестиционными институтами;

- государственная поддержка образования в области рынка ценных бумаг;

- приоритетное выделение государственных финансовых и материальных ресурсов для «запуска» рынка ценных бумаг;

- срочное создание государственной или полугосударственной системы защиты инвесторов и ценных бумаг от потерь, связанных с банкротством инвестиционных институтов.

В соответствии со статистикой индекс РТС в России снизился примерно на $72-75 \%$, в то время как аналогичные индексы в США - только на $35 \%$, в Китае снизились на $49 \%$, в Индии - на $40 \%$, Бразилии на $50 \%$. Таким образом, «импортные» причины падения капитализации можно оценить примерно в $35 \%$, но остальные $37-40 \%$ - это российские причины ${ }^{43}$.

В России доминируют внутренние факторы:

- «nерегрев экономики деньгами», когда нефтедоллары и кредиты по низким ставкам убеждали предпринимателей и государство, что такое положение продлится еще довольно долго, и в этой ситуации возможно финансирование высокорисковых инфраструктурных проектов, приобретение активов под залог этих же активов и так далее;

- высокая корпоративная задолженность. Более половины долгов - долги корпораций и финансовых организаций с государственным участием. При этом валютные резервы ЦБ росли ежегодно примерно в тех же величинах, что и корпоративная задолженность;

- снижение инвестиционной привлекательности и отток капитала из России. На российском фондовом рынке средства нерезидентов составляли до $70 \%$ от всех оборачиваемых средств. Поэтому именно с российского рынка деньги иностранными инвесторами выводились в первую очередь.

Для повышения стабильности рынка облигаций и преодоления сжатия кредитного рынка необходимо изменить политику в области выпуска государственных ценных бумаг. В период кризиса на фондовом рынке в 2007-2009 гг. происходило обесценение облигаций, принимаемых в залог под обеспечение рефинансирования ЦБ РФ коммерческих банков. Котировки некоторых выпусков ОФЗ снизились до 50-60 \% от номинала, а корпоративных облигаций упали еще сильнее. Следовательно, роль облигаций как залогового инструмента резко упала. В этих условиях большое значение стали играть беззалоговые кредиты ЦБ РФ ${ }^{44}$.

43 Информация с официального сайта РТС.

44 http://credit.rbc.ru/company_news/other/2008/11/10/62017.shtml 
В августе 2008 г. беззалоговые кредиты вообще не выдавались, а уже в ноябре на них приходилась подавляющая часть рефинансирования коммерческих банков. В условиях кризиса крупномасштабная выдача беззалоговых кредитов на сравнительно длительные сроки может спровоцировать их массовый невозврат. Учитывая критическую ситуацию в области рефинансирования, Банк России с начала 2009 г. ввел новую форму поддержки банков - субординированные кредиты. Однако желаемого результата это не дало. Объем рефинансирования продолжает сокращаться. Задолженность банков по беззалоговым кредитам уменьшилась, в результате доля средств ЦБ РФ в суммарных пассивах банков составляет всего 18 \%. Одна из главных причин недостаточного рефинансирования - недостаток надежных залоговых инструментов, то есть государственных ценных бумаг.

В начале 2010 г. предусматривалось выпустить ОФЗ на сумму 410 млрд руб. по номиналу в два раза больше, чем в 2008-2009 гг. Между тем с осени 2008 г. начался резкий рост доходности госбумаг, а средний срок погашения всех выпусков ОФЗ рыночного портфеля стал быстро снижаться.

Чрезмерно высокие объемы выпуска ОФЗ в 2009 г. способствовали сокращению денежной массы. Между тем безналичная денежная масса, по данным Банка России, сократилась с 10 642,7 млрд руб. на 1 сентября 2008 г. до 8 928,9 млрд на 1 июня $2009 \Gamma^{45}$. Эмиссия ОФЗ привела к дальнейшему снижению ликвидности банковской системы. В связи с этим ухудшаются условия кредитования экономики, станут возможными задержки платежей. Большое значение для стабилизации фондового рынка и увеличения залоговой базы для рефинансирования имеет увеличение выпуска ценных бумаг для населения. Подобные ценные бумаги не предназначены для активных операций на биржах и во внебиржевых структурах. Их главная функция - сохранять сбережения населения. Важные потенциальные ресурсы рынка сберегательных ценных бумаг - накопления граждан в наличной иностранной валюте. Увеличение выпуска сберегательных облигаций создает определенную альтернативу сбережениям в валюте.

Проведение антикризисных мер окажет позитивное влияние не только на рынок ценных бумаг, но и на финансовый рынок в целом. Снижение доходности облигаций будет способствовать уменьшению процентных ставок по кредитам. Стабилизация котировок ценных бумаг окажет положительное воздействие на устойчивость банковской системы, поскольку ценные бумаги являются важным объектом для вложения банковских ресурсов. Рост курсов государственных и корпоративных долговых бумаг расширит залоговую базу для рефинансирования ЦБ РФ коммерческих банков.

В ходе проведенного анализа концепций и стратегий по развитию фондового рынка следует обратиться к содержанию программных документов органов государственной власти РФ (концепций, доктрин, стратегий) в сфере регулирования финансового рынка и его элементов.

45 Годовой отчет о размещении государственных ценных бумаг. 
В целях развития рынка ценных бумаг Указом Президента РФ от 1 июня 1996 г. № 1008 «Об утверждении концепции развития рынка ценных бумаг в Российской Федерации» была утверждена одноименная Концепция ${ }^{46}$.

Распоряжением Правительства Российской Федерации от 1 июня 2006 г. № 793-р была утверждена «Стратегия развития финансового рынка Российской Федерации на 2006-2008 гг.». Стратегия определяла ключевые направления деятельности государственных органов в сфере регулирования финансового рынка России.

Фактически план мероприятий по реализации Стратегии содержал только проекты нормативных правовых актов, разрабатываемых по соответствующим направлениям деятельности государственных органов на 2006-2008 гг.

По состоянию на конец 2008 г. из 19 мероприятий Стратегии, по которым ответственным исполнителем являлась ФСФР России, выполненными являются только 5 (приняты и вступили в силу соответствующие законодательные акты), 12 проектов федеральных законов находятся в стадии доработки, при этом часть из них снята с контроля по просьбе ФСФР России и перенесена для дальнейшей доработки на более поздние сроки. Данная информация содержится в Отчете Счетной палаты от 15 мая 2009 г. ${ }^{47}$.

Необходимо отметить, что при этом основная часть законопроектов финансировалась, в том числе за счет средств, полученных российской стороной в соответствии с соглашением, заключенным с МБРР, о займе № 4029-РУ для финансирования «Проекта развития рынка капитала» ${ }^{48}$.

Проверенный в ходе проверки выборочный анализ результатов, достигнутых в рамках реализации указанного проекта, показал неэффективность работ по разработке и доработке ряда проектов федеральных законов, в том числе связанных со сроками предоставления проектов федеральных законов в Правительство Российской Федерации.

Целью настоящей Стратегии было превращение финансового рынка в один из главных механизмов реализации инвестиционных программ корпоративного сектора с одновременным созданием условий для эффективного инвестирования частных накоплений и средств обязательных накопительных систем. В 2006-2008 гг. необходимо было решить следующие задачи развития финансового рынка:

46 Доклад «О проблемах и перспективах развития российского фондового рынка в условиях кризиса мировой финансовой системы». Институт развития фондового рынка.

47 Отчет Счетной палаты Российской Федерации от 15 мая 2009 г. № 24К (661) «О результатах контрольного мероприятия «Проверка эффективности в 2008 г. действующего законодательства и нормативной правовой базы о финансовом рынке и рынке ценных бумаг в целях стабилизации финансовой системы в Федеральной службе по финансовым рынкам и Министерстве финансов Российской Федерации». С. 85-89.

48 Доклад «О проблемах и перспективах развития российского фондового рынка в условиях кризиса мировой финансовой системы». Институт развития фондового рынка. 
- обеспечение снижения уровня нерыночного инвестиционного риска на финансовом рынке путем обеспечения защиты прав и законных интересов инвесторов;

- осуществление реформы правового регулирования финансирования, направленной на ликвидацию экономически не обоснованных регулятивных препятствий в сфере развития рынка и создание условий для учета интересов профессиональных участников рынка, инвесторов и эмитентов при формировании политики регулирования финансового рынка.

Важнейшим условием достижения поставленной цели являлось формирование благоприятного инвестиционного климата в Российской Федерации, включая установление стабильных правил ведения бизнеса и предсказуемость нормативного регулирования и правоприменения. Создание благоприятного инвестиционного климата является комплексной задачей, в решении которой должны участвовать все органы государственной власти.

Итоги стратегии по состоянию на $2010 r_{.}^{49}$ : несмотря на воздействие мирового финансового кризиса на Россию, финансовый рынок в результате реализации мероприятий, предусмотренных Стратегией, претерпел качественные изменения. Доступ к рынку капитала получили большинство российских компаний, ведущих цивилизованный бизнес. Значительно увеличилось количество первичных размещений акций этих компаний на финансовом рынке. Существенно расширился ассортимент инструментов финансового рынка и услуг, предоставляемых финансовыми организациями гражданам и нефинансовым предприятиям. Были обеспечены конкурентные условия для проведения сделок с ценными бумагами и их надежный учет и хранение. Произошло ускорение развития институтов коллективных инвестиций. Среди инвесторов на финансовом рынке существенно выросла доля консервативных фондов, настроенных на долгосрочные вложения.

Значительно сократились совокупные потери инвесторов, возникающие в связи с нарушением их прав и законных интересов.

Предполагалось, что предусмотренные Стратегией мероприятия позволили бы обеспечить условия для опережающего развития финансового рынка по сравнению с темпами роста валового внутреннего продукта. Повышение уровня развития финансового рынка в 2006-2008 гг. характеризовалось следующими показателями:

- отношение стоимости имущества, составляющего совокупные чистые активы инвестиционных фондов, а также пенсионных накоплений и пенсионных резервов, к валовому внутреннему продукту удвоилось и по итогам 2008 г. составило $6 \%$;

- стоимость корпоративных облигаций в обращении по отношению к валовому внутреннему продукту также удвоилось (с 2,2 \% в 2005 г. до 4,5 \% в 2008 г.);

49 Доклад «О проблемах и перспективах развития российского фондового рынка в условиях кризиса мировой финансовой системы. Институт развития фондового рынка. 
- соотношение страховых премий и валового внутреннего продукта повысилось (с $3 \%$ в 2005 г. до 5 \% в 2008 г.);

- капитализация рынка акций по отношению к валовому внутреннему продукту достигла к началу 2009 г. $70 \%$;

- доля операций с российскими акциями на российских торговых площадках составила в 2008 г. не менее $70 \%{ }^{50}$.

Ожидалось, что в 2008-2009 гг. привлечение финансовых средств посредством размещения российскими компаниями акций и облигаций на внутреннем финансовом рынке составит не менее $20 \%$ инвестиций в основной капитал крупных и средних предприятий. С учетом привлечения кредитов и займов $\mathrm{y}$ российских банков и на международном рынке капитала этот показатель должен был достичь 35-40 \%. Однако кризис внес свои коррективы, и большая часть целей, установленных Стратегией, не была достигнута.

По результатам выполнения Стратегии и в соответствии с анализом Отчета Счетной палаты от 15 мая $2009 \Gamma_{.}^{51}$, необходимо отметить, что по состоянию на 2009-2010 гг. остались незавершенными определенные Стратегией такие важные задачи, как:

- развитие инфраструктуры финансового рынка;

- создание правовых механизмов, направленных инсайдерской торговли и манипулирования на финансовом рынке;

- правовое регулирование осуществления выплат компенсаций гражданам на рынке ценных бумаг;

- формирование массового розничного инвестора.

В Стратегии развития финансового рынка Российской Федерации на 2006-2008 гг., утвержденной Распоряжением Правительства РФ от 1 июня 2006 г. № 793-p p $^{2}$, указывалось в качестве негативного явления на несоответствие российского законодательства принципам Международной организации комиссий по ценным бумагам. Кроме того, в документе неоднократно указывается на необходимость использования международного опыта и соответствия международным стандартам:

- учетно-расчетной инфраструктуры фондового рынка;

- фондовых бирж;

- системы раскрытия информации;

- использования инсайдерской информации.

50 Доклад «О проблемах и перспективах развития российского фондового рынка в условиях кризиса мировой финансовой системы». Институт развития фондового рынка.

51 Отчет Счетной палаты Российской Федерации от 15 мая 2009 г. № 24К (661) «О результатах контрольного мероприятия «Проверка эффективности в 2008 г. действующего законодательства и нормативной правовой базы о финансовом рынке и рынке ценных бумаг в целях стабилизации финансовой системы в Федеральной службе по финансовым рынкам и Министерстве финансов Российской Федерации».

52 Стратегия развития финансового рынка Российской Федерации на 2006-2008 гг., утв. распоряжением Правительства РФ от 1 июня 2006 г. № 793-р // Росс. газ. № 120. 
Стратегия развития банковского сектора Российской Федерации на период до 2009 г. (приложение к Заявлению Правительства РФ № 983п-П13, ЦБ РФ № 01-01/1617 от 5 апреля 2005 r. $^{53}$ ) указывает на несоответствие международным нормам уровня защиты прав кредиторов. При этом в документе также неоднократно указывается на необходимость «создать правовые условия функционирования кредитных организаций в соответствии с международными нормами, определенными, в частности, в документе Базельского комитета по банковскому надзору “Основополагающие принципы эффективного банковского надзора”»:

- обеспечения соответствия деятельности кредитных организаций международным стандартам финансовой отчетности;

- внедрения международных стандартов аудита;

- совершенствования налогообложения кредитных организаций с учетом международного опыта;

- соответствия практики ликвидации банков международно признанным нормам;

- унификации законодательства Российской Федерации и норм банковского регулирования в соответствии с международными правилами и практикой в области документарных операций.

В Концепции национальной безопасности РФ, утвержденной Указом Президента РФ от 10 января 2000 г. № $24^{54}$, отмечается, что «важнейшее значение приобретает проведение сбалансированной кредитно-финансовой политики, нацеленной на поэтапное сокращение зависимости России от внешних кредитных заимствований и укрепление ее позиций в международных финансово-экономических организациях. О проблемах использования международного опыта и расширении международно-правового регулирования в Концепции не сказано.

Концепция внешней политики Российской Федерации определяет, что интересы России непосредственно связаны и с другими тенденциями, среди которых:

- глобализация мировой экономики. Наряду с дополнительными возможностями социально-экономического прогресса, расширения человеческих контактов такая тенденция порождает и новые опасности, особенно для экономически ослабленных государств, усиливается вероятность крупномасштабных финансово-экономических кризисов. Растет риск зависимости экономической системы и информационного пространства Российской Федерации от воздействия извне;

- усиление роли международных институтов и механизмов в мировой экономике и политике («Группа восьми», МВФ, МБРР ${ }^{55}$ и другие), вызванное объек-

53 Стратегия развития банковского сектора Российской Федерации на период до 2009 г. (приложение к Заявлению Правительства РФ № 983п-П13, ЦБ РФ № 01-01/1617 от 5 апреля 2005 г.).

54 Концепция национальной безопасности РФ, утв. Указом Президента РФ от 10 января 2000 г. № 24.

55 МБРР - Международный банк реконструкции и развития. 
тивным ростом взаимозависимости государств, необходимостью повышения управляемости международной системы. В интересах России - полноформатное и равноправное участие в разработке основных принципов функционирования мировой финансово-экономической системы в современных условиях.

Однако, как показано выше, данные положения не развиты в программных документах по финансовому рынку.

В.В. Путин, выступая на расширенном заседании Государственного совета 8 февраля 2008 г. и в Государственной Думе 8 мая 2008 г.56, определил как одну из стратегических целей - формирование в России мирового финансового центра, однако в опубликованном проекте Концепции долгосрочного социальноэкономического развития РФ до 2020 г. вопросы суверенитета на финансовом рынке не рассматриваются.

Учитывая необходимость совершенствования правового регулирования профессиональной деятельности на рынке ценных бумаг, стоит отметить, что в настоящее время происходит постоянное увеличение разрыва между потребностями современного рынка и существующим общим уровнем результативности функционирования системы органов исполнительной власти в целом, в том числе и в сфере рынка ценных бумаг. Президент Российской Федерации в своем ежегодном Послании Федеральному Собранию Российской Федерации отмечает, что сегодня колоссальные возможности страны блокируются громоздким, неповоротливым, неэффективным государственным аппаратом ${ }^{57}$. В связи с этим назрела насущная потребность проведения широкомасштабной правовой реформы, направленной на решение следующих задач:

Во-первых, необходимо модернизировать систему исполнительной власти в целом. Структура исполнительной власти должна быть логично и рационально устроена, а госаппарат - должен стать работающим инструментом реализации экономической политики.

Во-вторых, нужна эффективная и четкая технология разработки, принятия и исполнения решений. Ныне действующий порядок ориентирован не столько на содержание, сколько на форму.

В-третьих, нужно, наконец, провести анализ ныне реализуемых государственных функций, исключить излишние, дублирующие функции и сохранить только необходимые ${ }^{58}$.

Решение поставленных задач позволит повысить эффективность функционирования системы государственного регулирования экономических отношений и, как следствие, станет основой развития рыночных механизмов во всех отраслях национальной экономики.

56 Стенограмма выступления премьер-министра В.В. Путина 8 мая 2008 г. // Росс. газ. 2008. 8 мая.

57 Послание Президента РФ В.В. Путина Федеральному Собранию Российской Федерации // Росс. газ. 2002. 19 апр.

58 Там же. 
В «Российской газете» 12 апреля 2009 г. была опубликована «Стратегия развития финансового рынка РФ на период до 2020 г.» ${ }^{59}$. Разработчики документа считают, что меры, которые прописаны в документе, могут открыть финансовому рынку новые перспективы, полагая, что за 12 лет российский рынок сможет увеличить свою капитализацию более чем в 10 раз. Прежняя концепция ФСФР по развитию рынка была рассчитана на три года: с 2006 по 2008 гг. Многое из того, что было намечено, сделать не удалось. В первую очередь речь идет о законе об инсайде, о развитии производных инструментов, о формировании класса массовых инвесторов и т.д.

Что касается данной Стратегии, можно выделить два основных направления. Первое - это укрепление уже существующих механизмов по работе фондового рынка. Второе - снижение рисков, прежде всего инфраструктурных. В отношении надзора регулятор, коим является ФСФР, предлагает ввести единые требования к расчету капитала, которые будут соответствовать международным стандартам, а заодно и пересмотреть требования к размеру собственных средств - в сторону их повышения - в среднесрочной перспективе. В долгосрочной же - приблизить собственный капитал участников рынка к определению достаточности капитала по международным стандартам. Согласно документу к приоритетным задачам по развитию финансового рынка власти относят повышение его емкости и прозрачности, обеспечение эффективной рыночной инфраструктуры, формирование благоприятного налогового климата и совершенствование госрегулирования. По сравнению с предыдущим документом, проект стратегии существенно изменился. В частности, в новом варианте нет разделов по развитию пенсионной системы и коллективных инвестиций. Так как здесь, считают разработчики, требуются точечные решения, в первую очередь изменения налогового законодательства.

В планах Правительства стоит задача довести капитализацию публичных компаний к 2020 г. до 170 трлн рублей против 32,3 трлн, которые сложились к началу 2008 г. $^{60}$. Другими словами, после падения за последующие 12 лет рынок должен вырасти почти в 15 раз. Сделать это будет довольно сложно, так как разработчики пришли к выводу, что рынку потребуется минимум четыре-пять лет, чтобы достичь уровня, который сложился к началу 2008 г.

Большой вопрос и с развитием инвестиционных фондов, из которых за несколько последних месяцев инвесторы выводили в массовом порядке деньги. По планам разработчиков, показатель инвестиционных средств должен увеличиться к 2020 г. почти в 20 раз.

Соответственно 2020 г. и является тем рубежом, который покажет реальность и применимость разработанных стратегий развития фондового рынка Российской Федерации.

59 Стратегия развития финансового рынка РФ на период до 2020 г., Распоряжение Правительства РФ от 29 апреля 2008 г. № 2043-р «Об утверждении Стратегии развития финансового рынка Российской Федерации на период до 2020 г.» // Росс. газ. 2009. 12 апр.

60 Там же. 